\title{
Landforms along transverse faults parallel to axial zone of folded mountain front, north-eastern Kumaun Sub-Himalaya, India
}

\author{
Khayingshing Luirei*, S S Bhakuni and SAnjay S Negi \\ Wadia Institute of Himalayan Geology, Dehradun, India. \\ *Corresponding author. e-mail: ashingmikzoluirei@gmail.com
}

The shape of the frontal part of the Himalaya around the north-eastern corner of the Kumaun SubHimalaya, along the Kali River valley, is defined by folded hanging wall rocks of the Himalayan Frontal Thrust (HFT). Two parallel faults (Kalaunia and Tanakpur faults) trace along the axial zone of the folded HFT. Between these faults, the hinge zone of this transverse fold is relatively straight and along these faults, the beds abruptly change their attitudes and their widths are tectonically attenuated across two hinge lines of fold. The area is constituted of various surfaces of coalescing fans and terraces. Fans comprise predominantly of sandstone clasts laid down by the steep-gradient streams originating from the Siwalik range. The alluvial fans are characterised by compound and superimposed fans with high relief, which are generated by the tectonic activities associated with the thrusting along the HFT. The truncated fan along the HFT has formed a $100 \mathrm{~m}$ high-escarpment running E-W for $\sim 5 \mathrm{~km}$. Quaternary terrace deposits suggest two phases of tectonic uplift in the basal part of the hanging wall block of the HFT dipping towards the north. The first phase is represented by tilting of the terrace sediments by $\sim 30^{\circ}$ towards the NW; while the second phase is evident from deformed structures in the terrace deposit comprising mainly of reverse faults, fault propagation folds, convolute laminations, flower structures and back thrust faults. The second phase produced $\sim 1.0 \mathrm{~m}$ offset of stratification of the terrace along a thrust fault. Tectonic escarpments are recognised across the splay thrust near south of the HFT trace. The south facing hill slopes exhibit numerous landslides along active channels incising the hanging wall rocks of the HFT. The study area shows weak seismicity. The major Moradabad Fault crosses near the study area. This transverse fault may have suppressed the seismicity in the Tanakpur area, and the movement along the Moradabad and Kasganj-Tanakpur faults cause the neotectonic activities as observed. The role of transverse fault tectonics in the formation of the curvature cannot be ruled out.

\section{Introduction}

The present study is aimed at understanding the relationship between the development of the Quaternary landforms and transverse faults formed along the axial zone of the folded mountain frontal part across the Himalayan Frontal Thrust (HFT) in the north-eastern corner of the Kumaun Sub-Himalaya (figure 1). This is an important geomorphological site to observe the ongoing Himalayan tectonics (Valdiya 1992; Valdiya et al. 1992; Prakash et al. 2015). The HFT is the leading edge of the Himalaya, which is characterised by active faulting and associated uplift (Nakata 1972, 1989; Gansser 1981; Lavé and Avouac 2000; Thakur 2004; Agarwal et al. 2009, 2012). The southern limit of the Himalaya is being demarcated by the HFT across which sudden elevational change and

Keywords. Himalayan Frontal Thrust; outer Kumaun Himalaya; transverse structure; folded mountain front. 


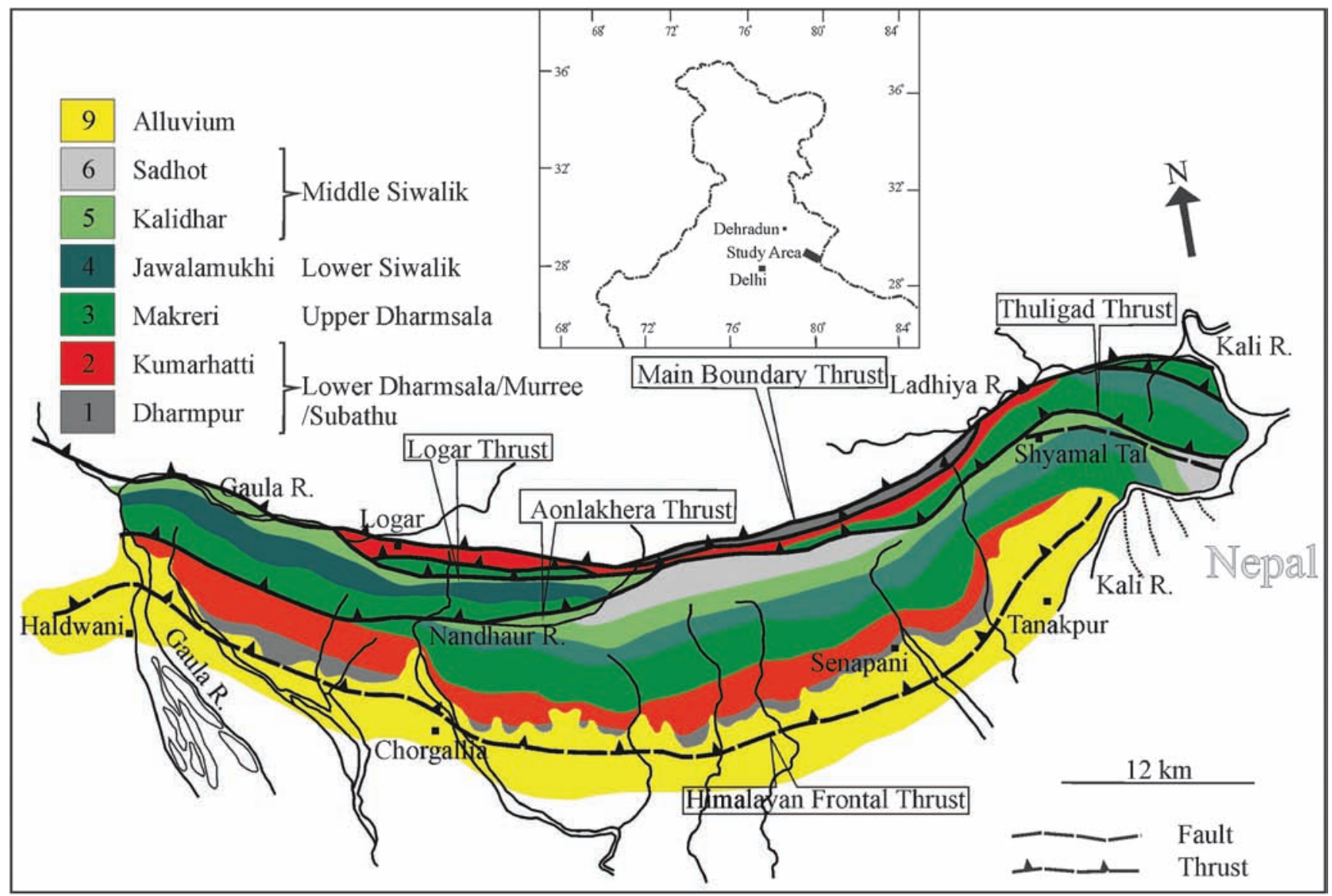

Figure 1. Geological map of the study area (Raiverman 2002).

exposure of the Siwalik rocks (Nakata 1972; Singh 1996). To the south of the HFT is the Piedmont Zone, which is the northernmost geomorphic element in the Ganga Plain (Pathak 1982; Singh 1996). This zone is divided into two geomorphic divisions known as the Bhabar and Terai (Pathak 1982; Singh 1996) that are characterised by subparallel to radiating drainage pattern of low drainage density (Shukla and Bora 2003). In the present study area, the Terai belt is not developed, whereas the Bhabar zone is either terminated as a result of the incision by the Kali River (Sarda River) or superimposed on $\mathrm{T}_{1}$ surfaces (Singh 1996; Goswami and Yhokha 2010). The Piedmont Zone is formed as a result of the coalescence of several alluvial fans and talus deposits, which are gravelly in the proximal part and silty-fine sandy in the distal part (Singh 1996; Goswami and Yhokha 2010; Goswami 2012). Recent tectonic activity in the frontal part of the Himalaya is expressed by varied geomorphological evidences such as the presence of tectonic escarpment, strath terraces, nick points along valley profile, deflection in drainage pattern and offsetting of the Siwalik rocks (e.g., Nakata 1972; Valdiya 1986, 2003; Valdiya et al. 1992; Shukla and Bora 2003; Thakur 2004; Goswami and Pant 2007, 2008; Agarwal et al. 2009, 2012).
Morphometric evidences of neotectonic block movement along the transverse fault in the outer Himalaya have also been reported from the Yamuna Tear Zone (Srivastava et al. 2013). Deformed Quaternary deposits have been described from various sites in the HFT zone, such as warping, tilting and truncation of fans and terraces and thrusting of the Siwalik rocks over the Quaternary deposits (Valdiya et al. 1992; Yeats et al. 1992; Malik and Nakata 2003; Goswami et al. 2013). Agarwal and Sharma (2011) and Goswami and Deopa (2012) have determined the Quaternary tilting of the tectonic blocks of the eastern Kumaun Himalaya. Occurring between the Himalaya and the Peninsular India, the Gangetic Plain is characterised by a variety of landforms and drainage systems (Singh 1996). On the basis of geomorphic surfaces, the Ganga Plain has been divided into the Upland Terrace Surface $\left(\mathrm{T}_{2}\right)$, Marginal Plain Upland Surface (MP), Megafan Surface (F), River Valley Terrace $\left(\mathrm{T}_{1}\right)$, Piedmont Fan Surface $(\mathrm{PF})$ and Active Flood Plain Surface $\left(T_{0}\right)$ that resulted from climate change and base-level-adjustment during the last 120 ka (Singh 1996). The Piedmont Fan (PF) surfaces, formed at the base of the Himalayan foothills, are relict features resulted due to coalescence of several fans. They are located in the 
Bhabar and Terai belts; the former composed of gravelliferous sediments with steep slopes and ephemeral streams while the latter is made up of silty-fine sand (Pathak 1982; Singh 1996). The surface outcrop shows that near the mountain foot the Piedmont deposits are gravelly (98\%) where cross-bedded gravel successions dominate and are both clast-and-matrix supported (Shukla and Bora 2003). Development of alluvial fans is affected by changes in the course of a cycle, varying base level, climatic changes, tectonic movements and slumping of fan deposits (Davis 1938; Blissenbach 1954). Tectonic activities are considered to be of prime importance in controlling alluvial fan sedimentation in active orogenic belts (Steel 1976; Heward 1978; DeCelles et al. 1991; Gupta 1997; Kumar et al. 2002). The deposition of alluvial fans in mountain front ranges is the obvious setting where a sediment supply controls the development of sedimentary geometries and sequences can be evaluated (Allen and Hovius 1998).

The present paper deals with the folded mountain front traversed by transverse faults, where the morphological features of fans are observed in the mountain front. This study has implication with the recent tectonic activity along the HFT and its splay thrust (Kotlia et al. 2008; Goswami and Yhokha 2010) that have deformed the Quaternary deposits, landforms and triggered the landslides in the area (Valdiya 1992; Valdiya et al. 1992).

\section{Geological setting}

Comprising the frontal part of the Himalaya, the Siwalik and pre-Siwalik rocks make up the Sub-Himalaya, while Piedmont surfaces constitute the foothills. The Sub-Himalaya (figure 1) is made up of sequences of the marine PaleoceneMiddle Eocene Subathu Formation, non-marine Oligocene-Lower Miocene Dharamsala Formation and fluvial Middle Miocene-Pleistocene Siwalik Group in the NW Himalaya (Karunakaran and Ranga Rao 1979; Powers et al. 1998; Raiverman 2002). The Subathu Formation comprises of green shales and grey marls that constitute the southernmost unit and are exposed along the mountain front, and in the north; it forms the footwall block of the Main Boundary Thrust (MBT). This, overlain by the Dharmsala Group ( Logar Formation), is made up of fine- to medium-grained, grey to greenish grey coloured sandstone and greyish green shales of Oligocene-Early Miocene age (Tiwari et al. 1991). The Siwalik Group is represented by the Middle and Lower Siwaliks, the conglomeratic sequence, comprising the Upper Siwalik, is missing (Karunakaran and Ranga Rao 1979; Raiverman 2002). The Lower Siwalik is made up of dark grey to brownish, fine- to medium-grained, massive sandstone, multi-storeyed salt-and-pepper sandstone and yellowish to reddish-brown mudstone. Cross-stratification, lamination and ripples are important structures in the sandstones. The Middle Siwalik consists dominantly of sandstone interbedded with thin clay, the sandstones are coarse grained, poorly cemented and pebbly (Karunakaran and Ranga Rao 1979). The Sadhot Formation representing the upper part of the Middle Siwalik is marked by massive conglomerates in the Cenozoic sequence, which comprise mainly of alternation of conglomerates, sandstones and clays (Raiverman 2002). Apart from Raiverman (2002), the pre-Siwalik rocks are also reported from south-eastern Kumaun SubHimalaya. Ranga Rao and Venkataraman (1959) discovered Nummulitic shale characteristic of the Subathu near Kathgodam, and Kumar (2004) described the Chunadhaki green claystones as possibly being time equivalent to the Murree. The Piedmont surface is made up of gravelliferous and silty-sand belts that are thought to have formed around the latest Pleistocene-Holocene times (Singh 1996; Shukla and Bora 2003). Structurally, it is bounded on the south by the HFT, where in most cases it is a blind thrust (Raiverman 2002).

\section{Material and method}

Survey of India (SOI) toposheet (1:63,360 scale), Digital Elevation Model (DEM-SRTM) and satellite data (Google Earth) have been used in conjunction with detailed geological field investigations to demarcate and analyse the escarpments and landforms. Apart from the geomorphic evidences of active tectonics, an attempt has also been made to compute the wedge failure analysis (Hoek and Bray 1977) to characterise the vulnerability of the steep slopes to landslides and related phenomena. The International Seismological Centre (ICS) earthquake catalogue was used to review the seismicity pattern around the Kumaun region.

\section{Aggradational landforms}

The depositional landforms have been grouped into (i) the alluvial fans and (ii) the fluvial deposits. In the study area, the alluvial fans occupy the relatively steeper portions, while the fluvial terraces occupy the flatter surfaces.

\subsection{Alluvial fans}

Along the mountain front of the Tanakpur area, fan surfaces are observed at the base of the steep south-facing hill slopes (figure 2). The fans are 

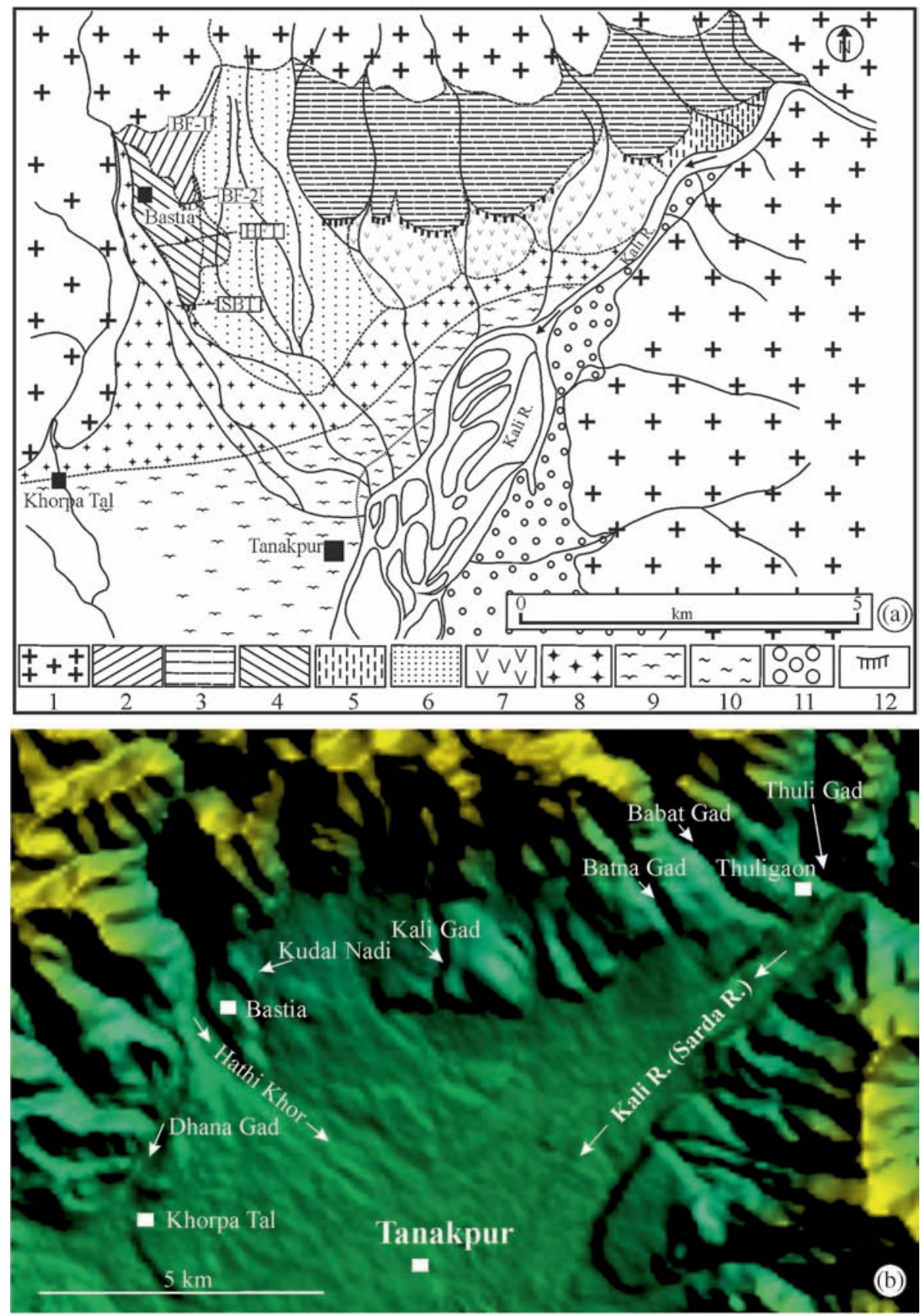

Figure 2. (a) Geomorphological map of Tanakpur area (modified after Valdiya 1992 and Valdiya et al. 1992). (b) DEM showing the topography of the terrain around Tanakpur. Incised fan sections are observed along Thuli Gad, Batna Gad, Babat Gad, Kali Gad and Hathi Khor. (1) Siwalik; (2) North Bastia Surface; (3) Batna Gad Fan; (4) Bastai Fan; (5) Babat Gad Fan; (6) Kudal Fan; (7) Recent Fan; (8) Unclassified Fan; (9) Terrace T2; (10) Terrace T 1 ; (11) Unclassified Quaternary deposit; (12) Escarpment; BF-1: Basti Fault-1: BF-2: Bastia Fault-2; HFT: Himalayan Frontal Thrust and SBT: South Bastia Fault.

basically debris cones formed by the sediments supplied mainly by landslides taking place in the hinterland and later transported by the streams. The hinterland is made up of rocks belonging to the Siwalik Group. Valdiya (1992) and Valdiya et al. (1992) have broadly divided the fans into the Bastia and Uchali Got Fans. In the present study, the fans have been further classified on the basis of variable heights, and the highest fan is designated as the Batna Gad Fan (BGF) formed by the coalescing of many smaller fans. It is observed in the east of Bastia that extends eastward up to Thuli Gad (figure 2). The fans are deposited by streams originating within the Siwalik terrain. They are entrenched by streams forming steep cliffs of more than $40 \mathrm{~m}$ high and the incision is most prominent at the HFT zone. The BGF sections are best exposed along the channels of Thuli, Babat, Batna and Kali Gads. Along Thuli Gad, the incised fan measures more than $40 \mathrm{~m}$ in height and is 

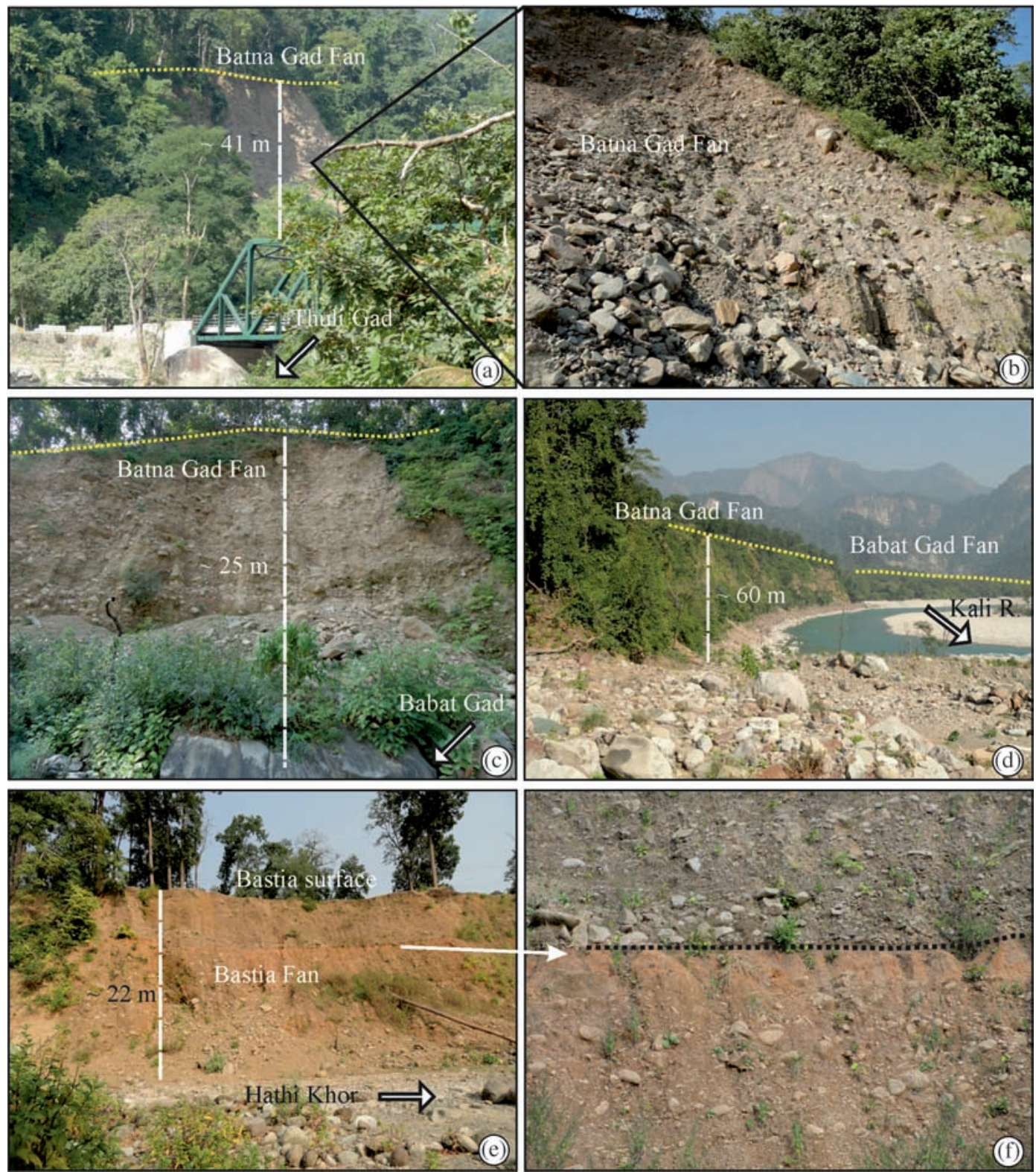

Figure 3. Field photographs showing exposed sections of fans. (a) Batna Gad Fan (BGF) exposed along Thuli Gad. (b) Close-up view of Batna Gad Fan. (c) Incised sequence of the Batna Gad Fan along Babli Gad. (d) BGF exposed along the Kali River, the exposed fan measures $\sim 60 \mathrm{~m}$. (e and f) Sections of Bastia Fan exposed along the Hathi Khor River. Break in sedimentation is marked by well-defined marker bed indicated by the dashed line.

composed mainly of the clasts of sandstones of the Siwalik (figure 3a, b). The sediments are clasts supported and crudely laminated with a maximum size of the clast $\sim 4 \mathrm{~m}$ in diameter; these are intervened by a thin layer of sandy horizon. Large boulders are observed towards the bottom section of the fan, and upward fining sequence is observed. Further downstream of Thuli Gad, near its confluence with the Kali River, the Lower Siwalik sandstones are exposed. Reworking of the fan by the Kali River is evident by the presence of well-rounded clasts in the fan composition, which is not the case a few hundred meters upstream of Thuli Gad. Along Babat Gad the $25 \mathrm{~m}$ high fan sediments are exposed that are composed of crudely laminated angular clasts of sandstone, with thin layers of gravelly sand in between (figure 3c). Erosion of the distal part of the BGF by the Kali River has exposed a $\sim 60 \mathrm{~m}$ thick fan deposit (figure $3 \mathrm{~d}$ ). The fan-section comprised mainly of clasts of sandstones of smaller dimension as compared with those observed along Thuli and Babat Gads. The BGF has been deeply incised by the Kali and Batna Gads. The Babat and Kudal Gads fans are covered with thick vegetation and are not incised by the streams; therefore, their sections are obscured. The Babat and Kudal Gads fans are made up of reworked sediments from the BGF with fresh 
landslide debris that came from the hinterland. The Bastia Fan is the most accessible of all the fans as the Hathi Khor river traverses throughout its length and the exposed segment measures $\sim 2.5 \mathrm{~km}$ in length, with a maximum height of $\sim 25 \mathrm{~m}$. In the proximal part of the fan, just north of Bastia, the bottom- and mid-sections of the fan consists of weathered, highly angular to sub-rounded clasts of sandstones with crude laminations, while the matrix consists of rock fragments with very coarse sand. The topmost portion of the fan is characterised by a sandy layer of $\sim 0.5 \mathrm{~m}$ thick, overlain by angular rock fragments. In the distal part, the exposed fan measures $\sim 22.5 \mathrm{~m}$ in height. The fan is made up mainly of the clasts of sandstone of various sizes; the sizes of the clasts are much smaller than those observed at the proximal part, due to the waning of the stream energy transporting the sediments. From the exposed section it appears that there was a time gap in the sedimentation as indicated by sharp contact between the two layers (figure 3e, $\mathrm{f}$ ). Break in the deposition is marked by a $\sim 1.5 \mathrm{~m}$ thick oxidised sand layers representing a marker layer. In the mid-section of the fan in the HFT zone, the fan sediment thickness is observed to be the least as the exposed section comprised of equal thickness of the Siwalik bed rocks and fan deposits. The youngest fans are characterised by almost barren surfaces. They are made up mainly of debris of landslides with very angular to angular clasts of sandstones of various dimensions. The latest alluvial fan deposit is the one that completely covered a portion of road section between Thuli Gaon and Tanakpur, which was laid down during the monsoon of 2010. Sediments are generated from massive landslides that took place in the steep south facing hill slopes.

\subsection{Terrace}

In the field, there is no clear cut demarcation of disposition between the fans and terraces, as the terraces are overlapped by fan deposits and thick forest cover. Two geomorphic units have been demarcated through the work of Valdiya et al. (1992) and Google Earth, toposheet and DEM-SRTM. Two levels of terraces are observed around Tanakpur area (figure 2a). The older Uchali Got Terrace $\left(\sim \mathrm{T}_{2}\right)$ is at the elevation of $\sim 272 \mathrm{~m}$ asl measured around Uchali Got, the younger Suwa Got Terrace $\left(\sim \mathrm{T}_{1}\right)$ is situated at $\sim 268 \mathrm{~m}$ asl, and the present river bed of the Kali River is at $\sim 257 \mathrm{~m}$ asl. Terrace $\mathrm{T}_{2}(2-3 \mathrm{~m}$ thick) is exposed along a number of streams flowing across the terrace and is best exposed around Uchali Got. This terrace is made up mainly of clasts (cobble size) of the Nagthat quartzite and Siwalik sandstones. The terrace $\mathrm{T}_{1}$ is similar to terrace $\mathrm{T}_{2}$ in composition; the main constituents being quartzite and sandstone. There is a gradual decrease in elevation between $T_{1}$ and river bed $\mathrm{T}_{0}$. Tectonically induced incision by Dhana Gad has exposed a 2-m thick terrace deposit, resting over the inclined pre-Siwalik rocks at Khorpa Tal (figure 4a). There is no distinct boundary separating the two levels of terraces of Khorpa Tal ( $\mathrm{T}_{1}$ of Khorpa Tal) and Uchali Got ( $\mathrm{T}_{2}$ of Uchali Got); only at Khorpa Tal, a $2-3 \mathrm{~m}$ break (vertical escarpment) is observed. At Senapani, one level of the terrace is observed in which the terrace sediments are laid down over the inclined pre-Siwalik rocks ( Dharmsala/Subathu) (figure $4 \mathrm{~b}, \mathrm{c}$ ). The terrace is made up clasts of sandstones and quartzite and the maximum size of the clasts are $\sim 30 \mathrm{~cm}$ in diameter. Compositionally this terrace differs from the one observed at Khorpa Tal. Here, a fair amount of representative

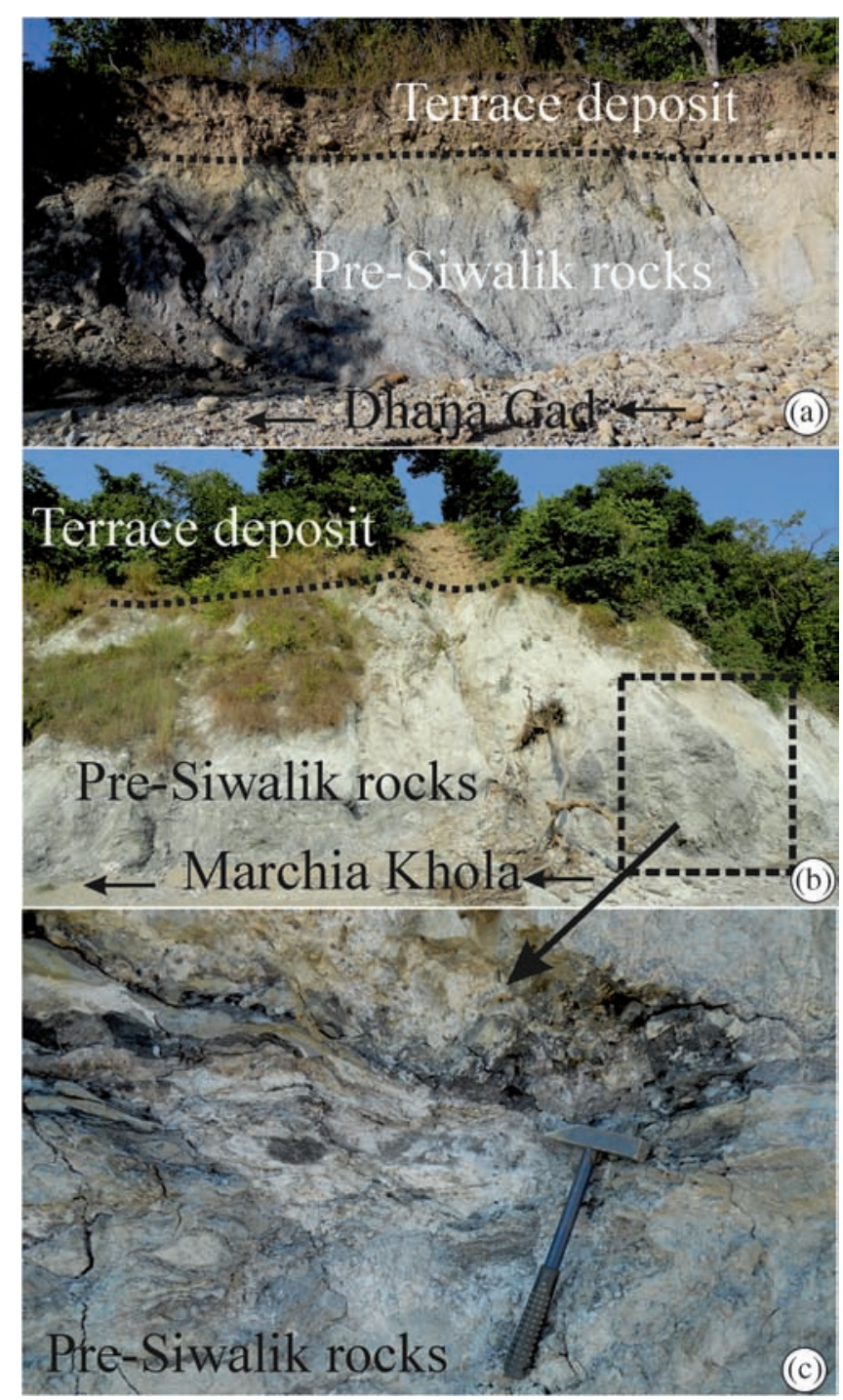

Figure 4. (a) Pre-Siwalik rocks exposed along Dhana Gad at Khorpa Tal in the HFT zone with terrace. (b and c) Highly sheared pre-Siwalik rocks exposed at Senapani overlain by the terrace deposit in the HFT zone. 
quartzite pebbles and gravels is observed in the terrace, though this stream originates within the Siwalik terrain. The Upper Siwalik sequence is exposed in the source region of Kalaunia River, as marked in the geological map of Karunakaran and Ranga Rao (1979).

\section{Hill slopes, landslides and their relation with fans}

Hill slopes and landslides have a direct relationship with fans in the foothills. The south facing hill

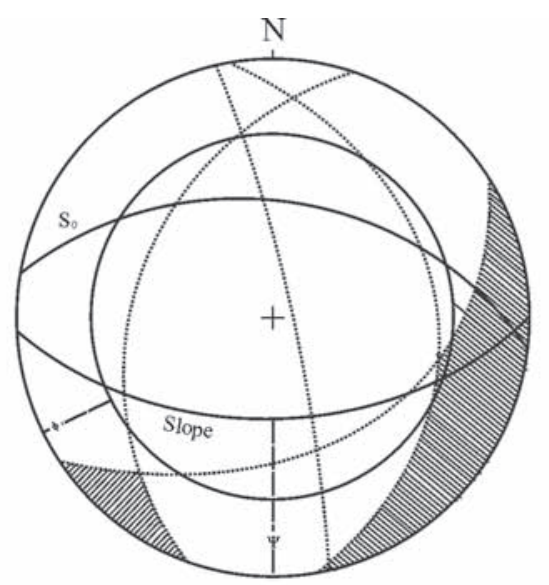

(a)
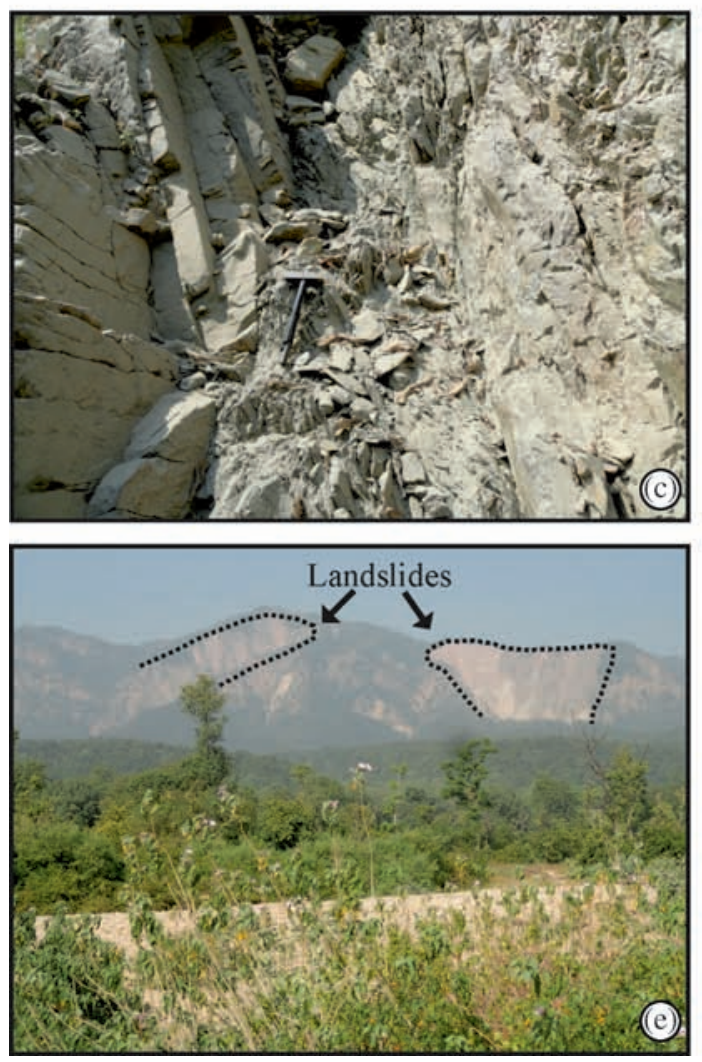

slope in the Tanakpur area is characterised by a sudden gain in elevation from $540 \mathrm{~m}$ asl measured at the proximal part of the fan to $\sim 1500 \mathrm{~m}$ asl at the ridge crest, within a distance of $2 \mathrm{~km}$. To characterise the type of landslides taking place in the area, two wedge failure analyses have been carried out. The first analysis indicates four joints forming wedges in the SE and SW quadrants, while in the second analysis, the bedrock is traversed by three joints forming a wedge in the SE quadrant (figure 5a, b). The rocks in the fault zone are highly sheared (figure $5 \mathrm{c}, \mathrm{d}$ ). The steep hill slope shows

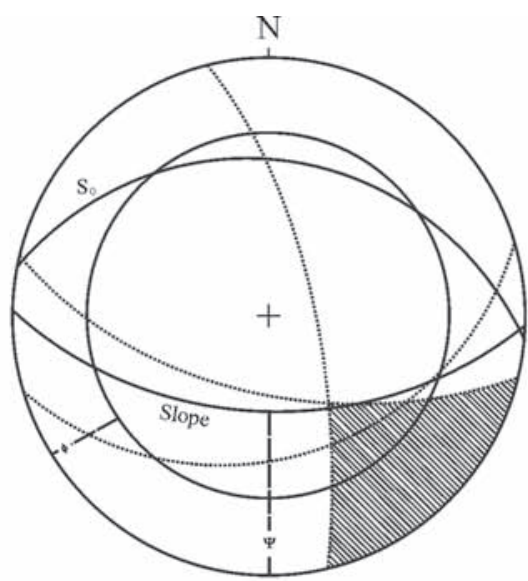

(b)
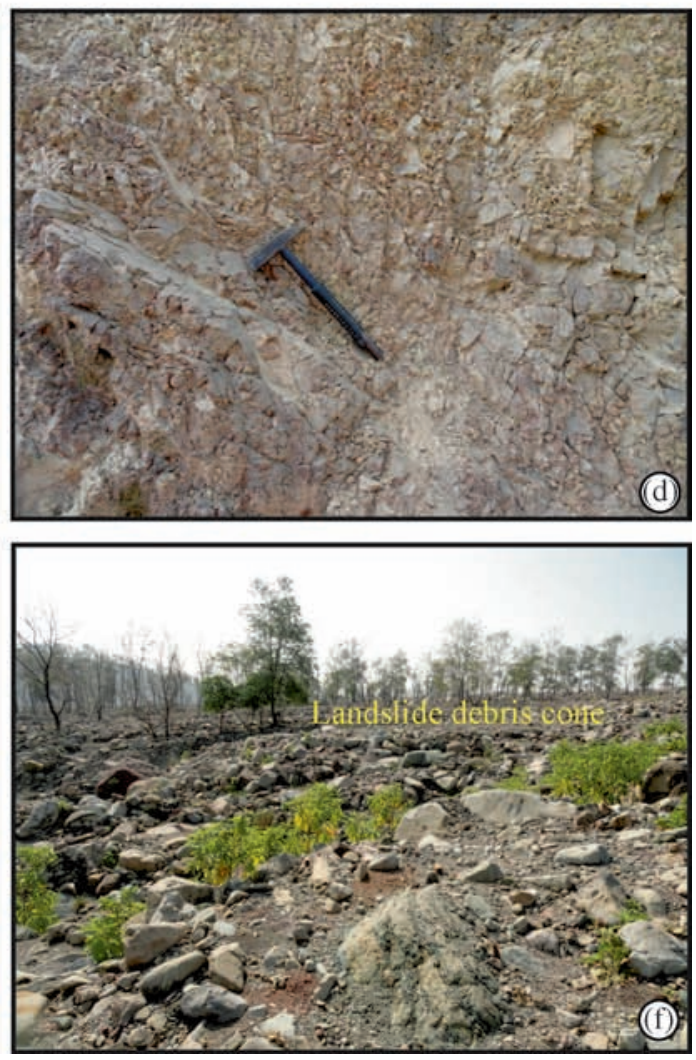

Figure 5. (a and b) Stereographic projections showing joints forming wedges in the open slope. The friction angle ' $\Phi$ ' has been assumed to be $30^{\circ}$. Shaded region indicates vulnerability to landslides. (c and d) Field photographs showing highly sheared rocks in the fault zone. (e) South facing slopes are dotted by number of old and active landslides; the photographs show huge crown of active landslides. (f) Huge landslide debris fan deposited during the monsoon of 2010. 
old and active landslides. Massive landslide is taking place in the catchment area of the Batna Gad; thereby generating huge debris (figure $5 \mathrm{e}, \mathrm{f}$ ). It is evident from the Google Earth image of 2006 that a landslide was active in the past, adjacent to the Batna Gad, but now the slide is inactive as evident by regeneration of vegetation on landslide scar. The adjoining area is dotted by a number of small and large landslides.

\section{Tectonic landforms}

In the Tanakpur area, major landforms have developed parallel to the faults. It implies that they are controlled by tectonic activities. Kotlia et al. (2008) briefly mentioned the existence of the North Bastia Fault and the South Bastia Fault on the basis of the existence of fault gouge along the traces of the faults. The present study on landform suggests the existence of another fault between these faults, which are named as the Bastia Fault-1 (BF-1) and Bastia Fault-2 (BF-2). Towards the extreme south of Bastia, the South Bastia Thrust (SBT) is interpreted as a blind thrust, as no Siwalik bedrocks are exposed, but, nevertheless, an escarpment is observed along this fault. BF-1, BF-2 and SBT are interpreted to be splay of the HFT (figure 6). In the present study, BF-2 and HFT correspond, respectively, to the North Bastia Fault and South Bastia Fault of Kotlia et al. (2008). The BF-1 is the northern-most fault across which sudden change in hill slope gradient is observed with the development of brittle shear zones. The change in slope gradient across the BF-1 is regarded as relic mountain front where deformation has shifted southward. In the present study, the active mountain front is observed south of Bastia along the HFT (figure 6a, b). The shear zones related to faulting are best observed along the channel of Hathi Khor and the Tanakpur-Sukhidhang section is also shown by Prakash et al. (2015). The hanging wall block of the BF-1 shows recurrent landslides, and the rocks have been weakened by two prominent joint sets, forming a wedge towards the daylight slope. The footwall of the BF-1 is a flat barren rock surface and is designated as the North Bastia Surface (NBS), which resulted from faulting along the BF-2 and is $\sim 400-\mathrm{m}$ wide, although its length cannot be measured due to a thick vegetation cover and covering by colluvial deposit (figure 6c, d). The NBS is separated from the Bastia Surface by $\sim 20 \mathrm{~m}$ high tectonic escarpment, and the top of the hanging wall is characterised by highly sheared rocks. Faulting along the BF-1 and BF-2 has formed a tectonic wedge, north of Bastia. Along the HFT, a fault gouge has formed that is best exposed along the Hathi Khor where moderately inclined sheared
Siwalik rocks are exposed, covered by $\sim 5 \mathrm{~m}$ fan/ terrace deposit. Across this thrust, a sudden change in slope gradient is observed. Further south of the HFT, no Siwalik rocks are exposed (figure 6e). The Bastia Surface is separated from the unclassified fan by the SBT (figure $6 f, \mathrm{~g}$ ) along which a $~ 17-\mathrm{m}$ high escarpment trending $\mathrm{E}-\mathrm{W}$ is observed. This escarpment runs for $\sim 5 \mathrm{~km}$, punctuated in between by erosion and deposition of recently deposited alluvial fans. The highest escarpment is observed east of Bastia, extending up to Batna Gad between Kali Gad and Batna Gad, where it measures more than $100 \mathrm{~m}$ high. Between Kudal Nadi and Kali Gad, the escarpment has been eroded and depositions of newer fan deposits are observed at the foot of the escarpment. Thrusting along the HFT has lead to the incision of the fans by numerous streams forming V-shaped valleys. West of Tanakpur at Khorpa Tal, a topographic break of $\sim 2-3 \mathrm{~m}$ is observed, where uplift along the HFT has exposed $\sim 1.5 \mathrm{~m}$ high terrace deposit resting over the highly sheared inclined Subathu rocks. Change in the strike of beds from almost NE-SW in Senapani, west of Tanakpur to E-W around Bastia, north of Tanakpur, and to almost N-S near the confluence between Thuli Gad and Kali River, corroborates the existence of structural anomaly due to the presence of faults, and which resulted in the curvature of the mountain range.

\section{Folded mountain front}

The regional trend of the mountain front in the NW Himalaya is NW-SE, but it locally becomes SW-NE towards the north of Tanakpur and NW$\mathrm{SE}$ and $\mathrm{N}-\mathrm{S}$ at the exit of the Kali River near Thuligaon. This variation in trend of mountain front is due to the presence of a syntaxial structure. The N-S trending Thuli Gad and other stream, at $1.2 \mathrm{~km}$ east of Thuli Gad, flow along the axial zone of this major fold. These tributaries follow the $\mathrm{N}-\mathrm{S}$ trending brittle axial planar fracture cleavages of fold. The Kalaunia Fault offsetting the trace of the Bastia Fault (Goswami 2012) and the Tanakpur Fault, as shown in figure 8(b), are also parallel to these tectonic fabrics. At Bastia, the Siwalik rocks dip towards north direction, while near the confluence of Thuli Gad and Kali River, the bed rocks dip towards the ENE/E direction. At Senapani, the bedrocks comprise of the preSiwalik rocks ( $\sim$ Dharmsala/Subathu) where the attitude of the bedrock is moderately $\left(37^{\circ}-50^{\circ}\right)$ dipping towards N20W-N15W. Here the strike of the mountain front is almost E-W. Further east at Khorpa Tal, north-west of Tanakpur, the attitude of the bedrock is moderately dipping $\left(34^{\circ}-35^{\circ}\right)$ towards west-N80W, while the trend of the 


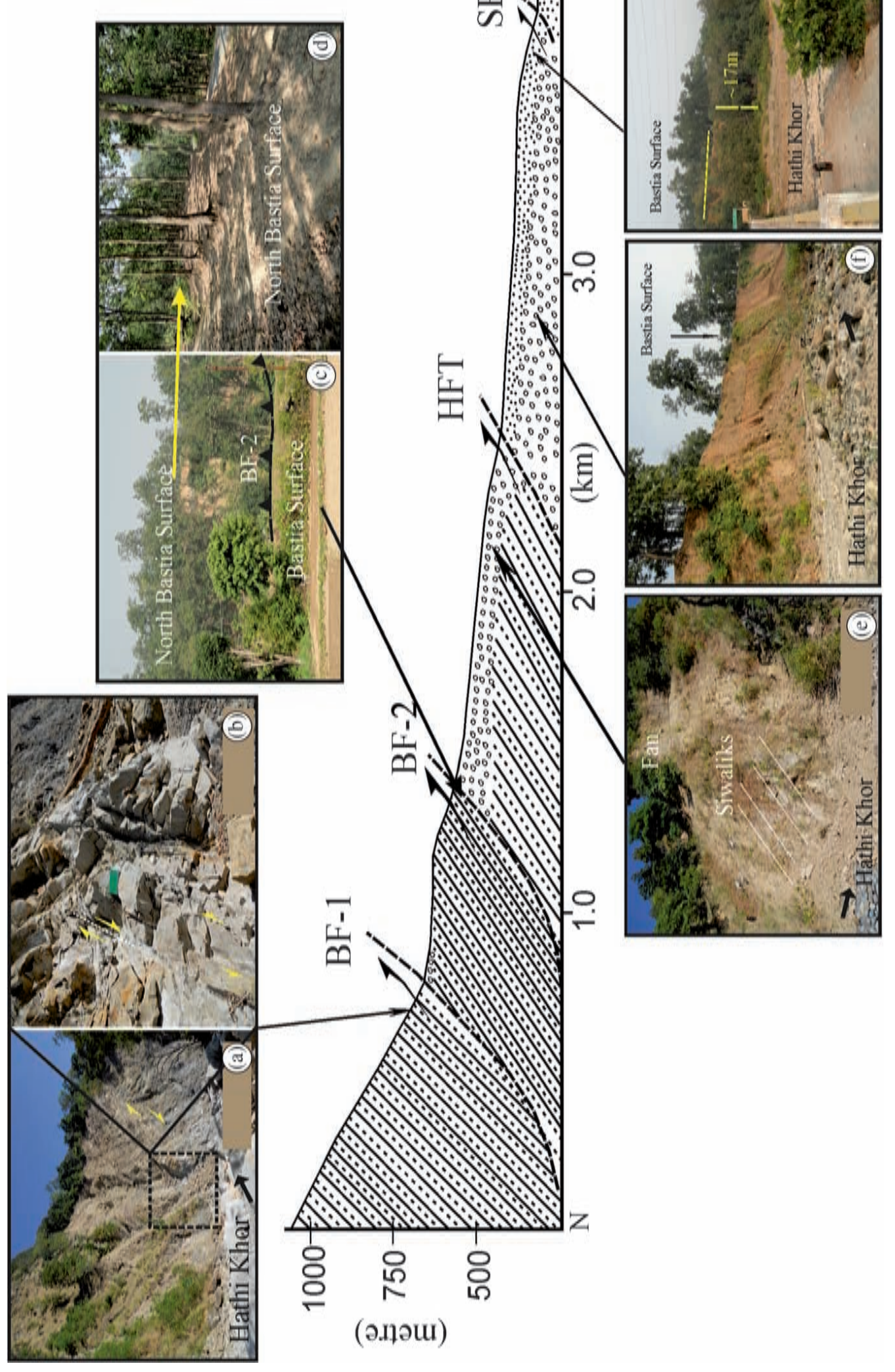

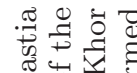

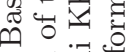

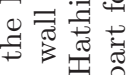

की

ชี

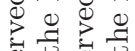

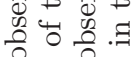

늘 छै कै

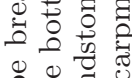

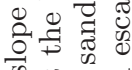

कै

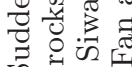

के

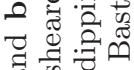

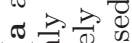

बं.

สี ชิ

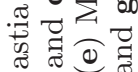

$\oplus$ U

$\stackrel{1}{\square} \dot{8}$

㟧。․․․

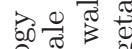

每

है

저

\&. 원

ㄴ.

苛菏

\pm 政

Ð

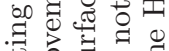

. ํㅐ

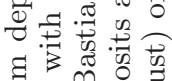

嘀

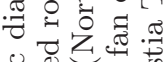

密 80

可

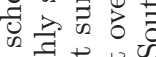

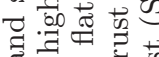

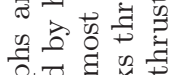

준.

넝

人, 范

긍 궁

证步

0 只西鼠

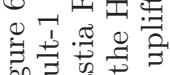

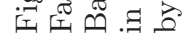


mountain front becomes NE-SW. At Khorpa Tal, the mountain front shows a $2-3 \mathrm{~m}$ high southdipping gentle fault scarp. The attitude of bedrock along the Hathi Khor River, west of Bastia, just at the point of exit into the Piedmont Zone, the bedrock dips $57^{\circ}-73^{\circ}$ towards N53W-N40W. Along the Tanakpur-Champawat highway, just north of Bastia, the attitude of the bedrock dips moderately $\left(44^{\circ}-52^{\circ}\right)$ towards $\mathrm{N}-\mathrm{NNE}$, and in this section, the trend of the mountain front is almost E-W with a slight curvature. Sudden change in slope gradient is observed along this section and is characterised by sheared bedrocks. This is the relict mountain front, where the present active mountain front lies south of Bastia at $\sim 3 \mathrm{~km}$ from the former. At Thuligaon, where the Kali River exits into the Piedmont Zone, the attitude of the bedrock becomes steeply dipping $\left(60^{\circ}-70^{\circ}\right)$ towards N80E-S40E (figure 7). At the Thuligaon section, the mountain front becomes NESW trending and the Kali River flows parallel to the strike of the bedrock. Before cutting across the Tanakpur Fault, the Kali River flows across the bedrocks perpendicularly (figure 7a, b), where the strike of bedrock is almost $\mathrm{N}$ $\mathrm{S}$ and flow direction of the Kali River is W, thereby resulting in a deep cut $\mathrm{V}$-shaped valley. The bedrock is subjected to brittle deformation as evident from bedding parallel movement having slickensides indicating a sense of movement
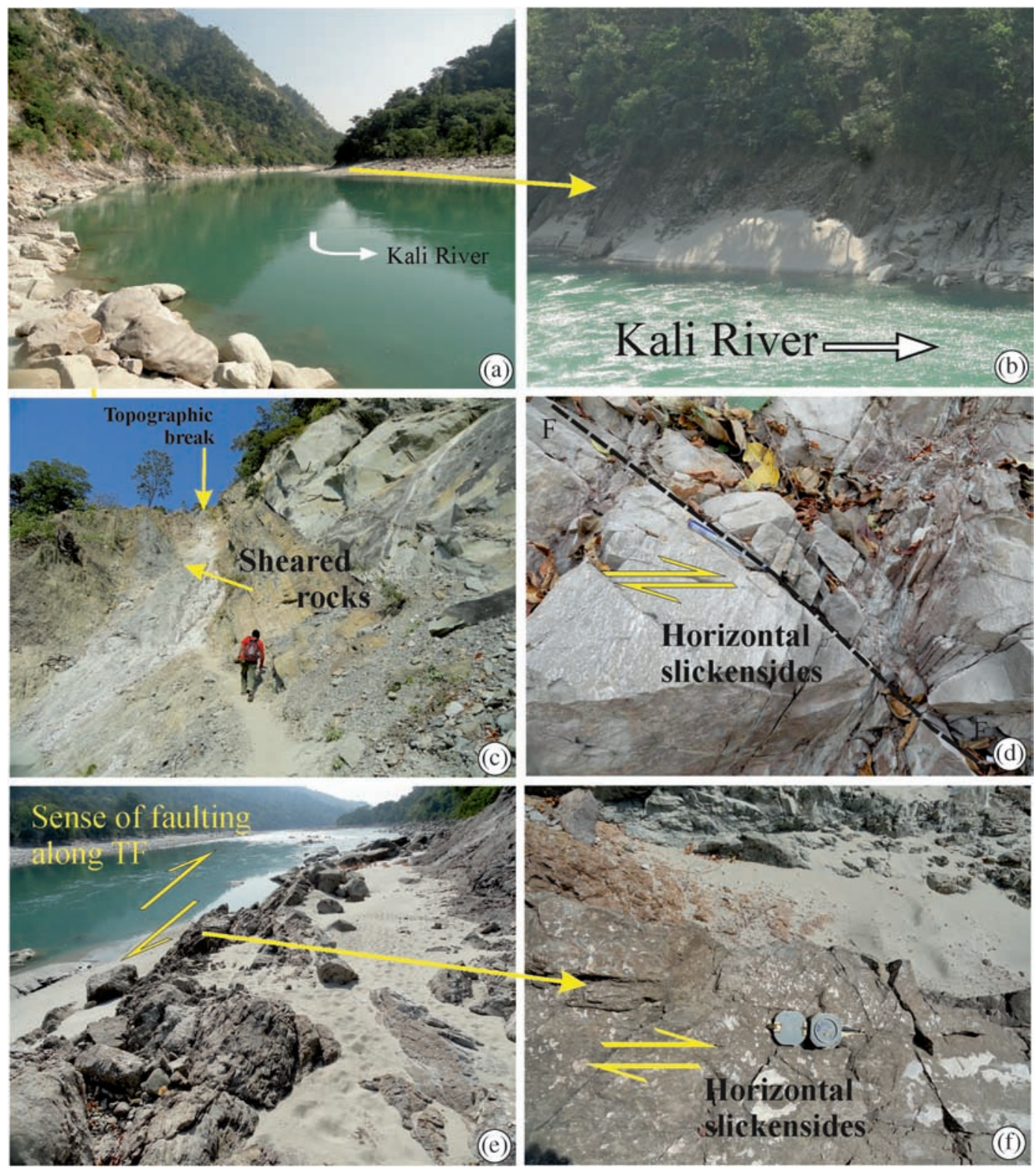

Figure 7. (a and b) Photographs showing the exit of Kali River into the Gangetic Plain at Thuligaon, the bedrock dip steeply towards NE. (c and d) Bedrocks characterised by bedding-parallel movement and the original fabric of the rock has been deformed; horizontal slickenside is also observed. (e and f) SE-dipping bedrocks exposed along the Kali River with horizontal slickenside indicating the sense of movement. 

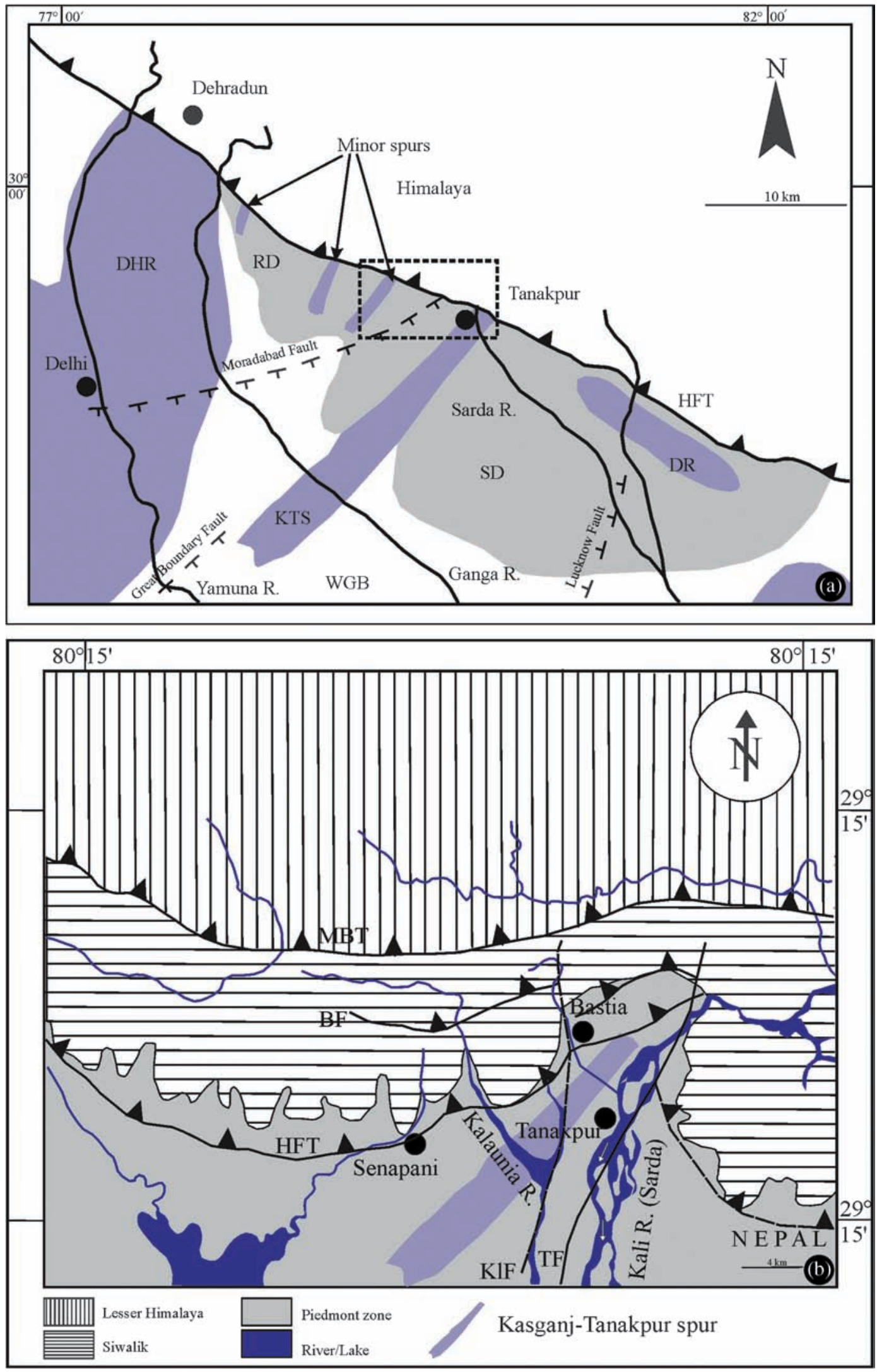

Figure 8. (a) Tectonic features of the basement of the Ganga Basin (Goswami 2012). (b) Morphotectonic map of Tanakpur area (Goswami 2012). MBT: Main Boundary Thrust, HFT: Himalayan Frontal Thrust, BF: Bastia Fault, KlF: Kalaunia Fault and TF: Tanakpur Fault. 
(figure $7 \mathrm{c}, \mathrm{d}, \mathrm{e}, \mathrm{f}$ ). The sense of movement on the bedrock is similar with the sense of movement indicated in figure 4 of Goswami (2012). Raiverman (2002) has discussed the existence of localised syntaxial bend, north of Tanakpur, due to the indentation of the Delhi-Moradabad ridge into the Sub-Himalaya. Tanakpur area is traversed by right lateral transverse faults, the Tanakpur Fault trending NNE-SSW (Valdiya 1976; Goswami 2012) (figure 8a). The transverse fault produced pronounced displacement that has placed different lithologies in juxtaposition (Valdiya 1976). Goswami (2012) also postulated a N-S trending fault, west of Tanakpur, on the basis of conspicuous dextral movements of the lithounits and also from number of cliff and landslides along this fault, and named it as the Kalaunia Fault (figure 8b).

\section{Deformed Quaternary deposits}

At Senapani, the tectonic induced erosion has exposed a 30-m high escarpment comprising of $16 \mathrm{~m}$ high of the pre-Siwalik rocks ( $\sim$ Dharmsala/Subathu) and $14 \mathrm{~m}$ high of terrace deposits. The dip of the pre-Siwalik rocks is $45^{\circ}$ towards NW direction (figure 9a). Overlying the pre-Siwalik rocks is the base of the terrace with angular unconformity between them. Stream cutting across the 30-m high escarpment has exposed the terrace that is made up mainly of clasts of the Siwalik sandstones and quartzite, which is $\sim 2.7 \mathrm{~m}$ thick. This is overlain by $\sim 2.26 \mathrm{~m}$ thick horizons of pebbles and laminated sand. Pebbles and laminated sand horizon are characterised by an upward fining sequence. Pebbles are made of quartzite and sandstones. The top horizon is made up of a thick sequence of cobbles and pebbles of $\sim 9 \mathrm{~m}$, made up of clast of quartzite and sandstones. The terrace sediments are tilted by $\sim 30^{\circ}$ towards the NW direction; the tilted sediments are characterised by hosts of deformation structures (figure 9b, $c$ and $\mathrm{d}$ ). The main deformation structures observed are the closely spaced reverse faults, dipping $38^{\circ}$ towards NW direction (figure 10a, b).

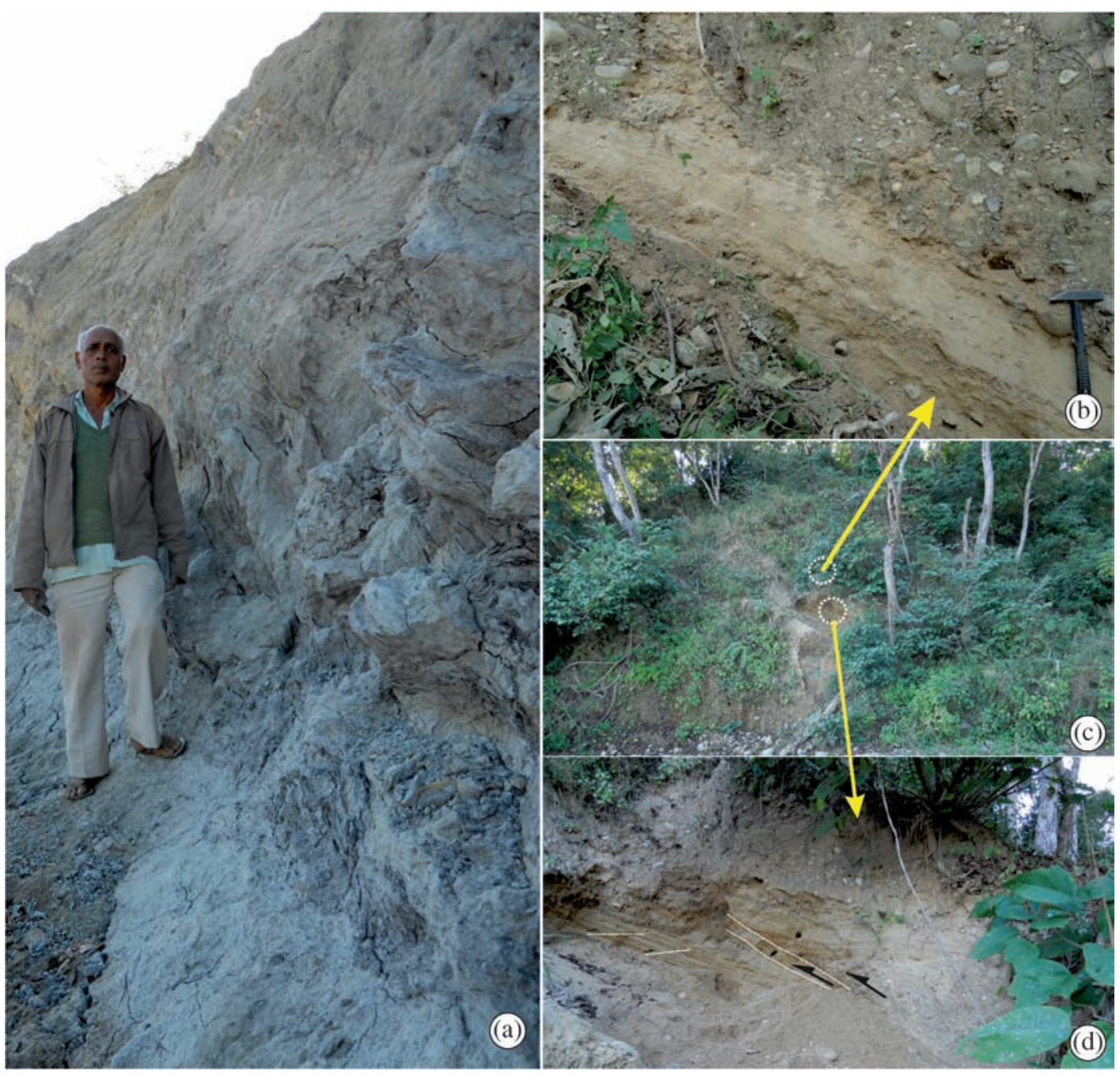

Figure 9. (a) Highly sheared pre-Siwalik rocks with moderate dip exposed at Senapani. (b, c and d) The pre-Siwalik rocks are overlain by terrace deposits which are tilted and faulted. 

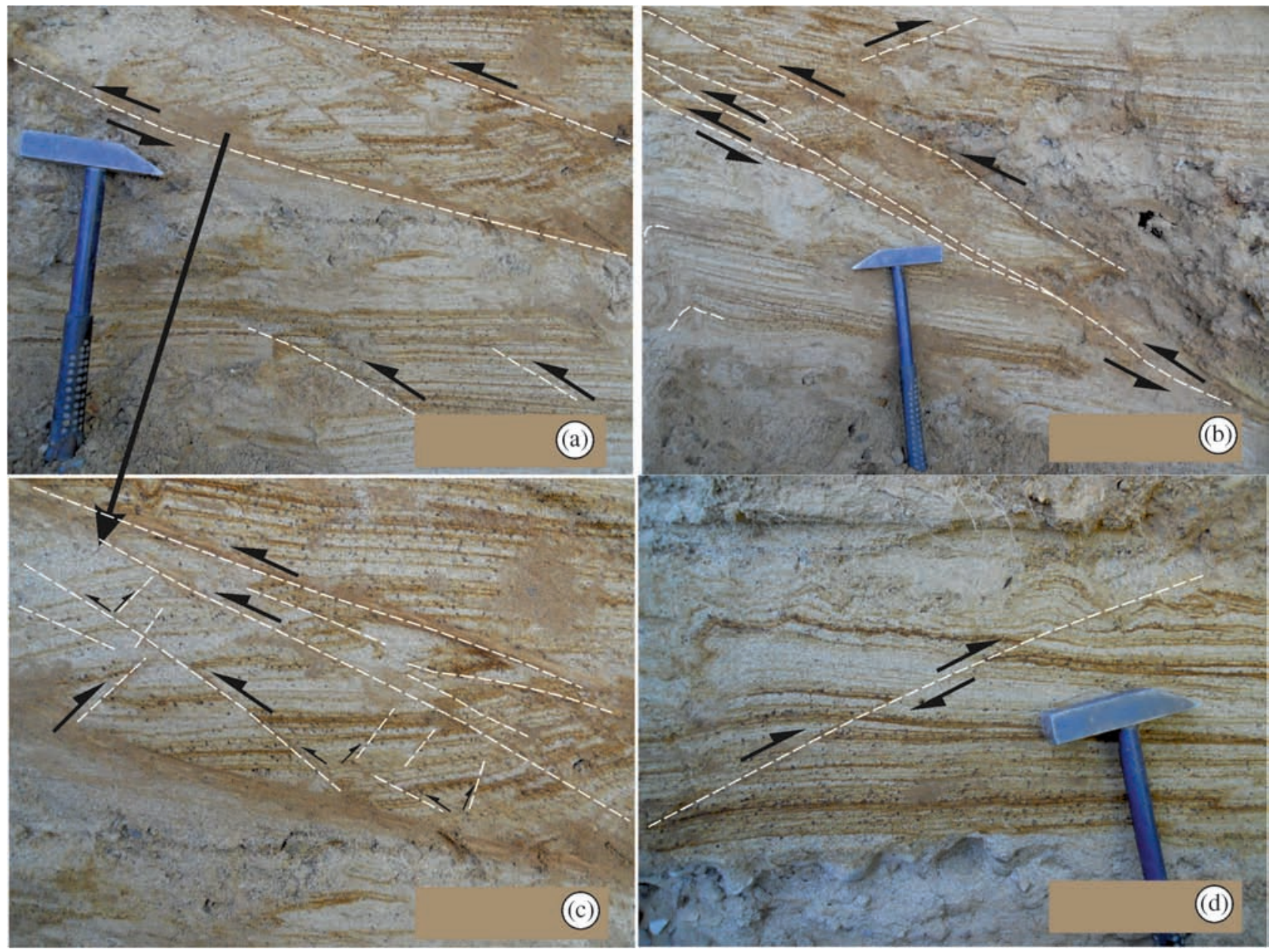

Figure 10. Tilted Quaternary terrace deposit at Senapani in the hanging wall of the HFT. Various deformed structures are embedded within the deposit. Tilting and deformed structures representing different phases of tectonic activity along the HFT. Sense of movement is indicated by arrows.

Maximum displacements have occurred mainly along the basal and the uppermost faults; in between which faults of smaller extent are also observed (figure 10c). The movement along the basal fault has resulted in placing the laminated sand over the upper pebbly horizon. Faulting along the uppermost fault has moved the underlying pebbly horizon forming the base of the laminated sand by $\sim 65 \mathrm{~cm}$ over the laminated sand layer. The maximum displacement along the uppermost fault measures to about a meter. In between the basal fault and the uppermost fault, the NW-dipping laminations have become horizontal to SE-dipping that resulted from the movement along successive minor faults (figure 10c). The reverse faults are associated with other deformed structures, such as crumpled lamination at the top of the thrust plane, kink folds, and wavy undulation of laminations, pop-up structure and folding. Faulting in opposite directions has resulted in small scale flower structures (figure 10c). Fault propagation folds are also observed towards the top of the deformed laminated sand (figures $9 \mathrm{~d}$ and 10d).
Small-scale parallel reverse faults resembling back thrusting are also observed that dip $7^{\circ}$ towards SE direction. The back thrusts are gentler than the main fore fault.

\section{Seismicity and lineaments}

Bouguer gravity data reveal several continuous Himalayan cross-strike discontinuities, which are interpreted to represent the crustal faults (Godin and Harris 2014), both orogen-parallel and orogentransverse. The stress change resulting from the active rifts could partly suppress the seismicity in an area (Gahalaut and Arora 2012). The seismicity along the Himalayan arc may also be influenced by the stress changes due to the interaction of faults in the Himalaya and Tibet, and by the occurrence of great and major earthquakes along the arc (Gahalaut et al. 2011).

In recent years, field-based active tectonic studies have been focused on understanding the strain rates of the active structures in the 
Himalayan frontal zone (Wesnousky et al. 1999; Lavé and Avouac 2000). Their study highlights the major seismicity zone occurring near to surface trace of the MCT and above the mid-crustal ramp, which during the interseismic periods may activate only a fraction of the area beneath the Lesser Himalaya. The whole flat, up to the HFT, would only be activated during the $\mathrm{M}>8$ major events. Thus, the influence of seismicity in the Lesser Himalaya would not participate in the active deformation near the HFT.

However, Jackson and McKenzie (1984) explained that the deformation is not distributed uniformly over the whole area of the active zone, but is concentrated in belts. These active belts, spreading hundreds of kilometres in width, may surround the relative aseismic areas. Within such deforming regions, continuum theory is required for a description of the kinematics, even though much of the motion is concentrated on active faults. Their study further state that the evolution of fault systems within the active zones is controlled by geometric constraints. A basic geometrical limit required for simultaneously active faults is that they do not generally intersect (Jackson and McKenzie 1984). The other case when the faults intersects could be described from the study by Robinson et al. (2006), which reveals that the earthquake rupture zones are affected and delimited by regional tectonics and subsurface ridges that act as a barrier for the rupture front with no further slip across them, hence produce segmentation in seismic zones most likely due to the structural heterogeneities on the converging plates (Gahalaut and Arora 2012). The structural complexities that appear to control the spatial variation in the Himalayan seismicity include presence of subsurface ridges on the underthrusting Indian plate (Valdiya 1976; Gahalaut and Arora 2012; Godin and Harris 2014), the geometry of the detachment (Ni and Barazangi 1984) and the midcrustal ramp (Pandey 1995) as well as the active rifts in the overriding Himalayan wedge (Armijo et al. 1986). Moradabad Fault is a major lineament zone that traverses near to the west of the study area (Sastri et al. 1971; Karunakaran and Ranga Rao 1979; Raiverman 2002; Godin and Harris 2014).

We used International Seismological Centre (ISC) reviewed earthquake catalogue to assess the seismicity pattern around the Kumaun region focusing the seismicity along the Moradabad Fault (figure 11). The earthquake locations give reliable estimates, assured by rigorous checks for inconsistencies and errors (http://www.isc.ac.uk/iscbulletinsearch/ catalogue/). Figure 11 shows the epicentres and focal mechanism plots for $\mathrm{M} \geq 3.5$ (filled black circle) and $\mathrm{M}>4.5$ (star in red) earthquakes, respectively, from the year 1960 to 2012. The focal mechanism results are used from the global Centroid Moment Tensor solutions, where the method to determine the solutions has been discussed in detail by Dziewoński et al. (1981) and Ekström et al. (2012). We observe the feeble seismicity patch towards the Himalayan frontal part near the HFT which is nearly absent along the surface trace of the Moradabad Fault. We are limited to comment on the seismicity near the MCT along the surface trace of Moradabad Fault, which could more likely be influenced by the activity along the mid-crustal ramp. The focal mechanism near the study area indicate north-dipping thrust fault and does not indicate any sense of movement which could be related to the NE-SW striking the Moradabad Fault. Therefore, under the studies based on rupture velocity, stress, strain and seismicity analysis, we infer that Moradabad Fault could be an important structural heterogeneity suppressing the seismicity in the Tanakpur area (figure 11). However, the movement along the Moradabad Fault can cause the neotectonic activities in the study area (Valdiya 1976; Goswami and Yhokha 2010; Goswami 2012).

\section{Discussion}

Raiverman (2002) has discussed the existence of localised syntaxial bend (here referred as the folded mountain front) due to the indentation of the Delhi-Moradabad ridge into the Sub-Himalaya at a high angle $\left(70^{\circ}-80^{\circ}\right)$ to the Himalayan strike resulting for a syntaxial bend, north of Tanakpur. Similar syntaxial bend is also reported from Kotdwar area (Raiverman 2002). The folded nature of the mountain front is also explained by the existence of two transverse faults, i.e., Tanakpur and Kalaunia faults (Valdiya 1976; Goswami 2012; Srivastava et al. 2013). Goswami (2012) is of the view that the active Tanakpur and Kalaunia faults represent the rejuvenated basement faults related to Kasganj-Tanakpur-Spur. However, Srivastava et al. (2013) argued that these transverse faults are lateral ramps or connecting splays and are present throughout the mountain front, giving it a very conspicuous sinuosity. The present observation such as swing in the strike of the bedrock attributes to this spur. The NNE trending folded mountain front measures $\sim 8 \mathrm{~km}$ in width. The aggradational landforms especially the alluvial fans have been dealt in relation with the nature of the slopes and landslides. There is a sudden gain in elevations from $540 \mathrm{~m}$ asl measured at the proximal part of the fan to $\sim 1500 \mathrm{~m}$ AMSL at the ridge crest within a distance of $2 \mathrm{~km}$. The nature of the slopes has direct bearing with the active HFT, which has 


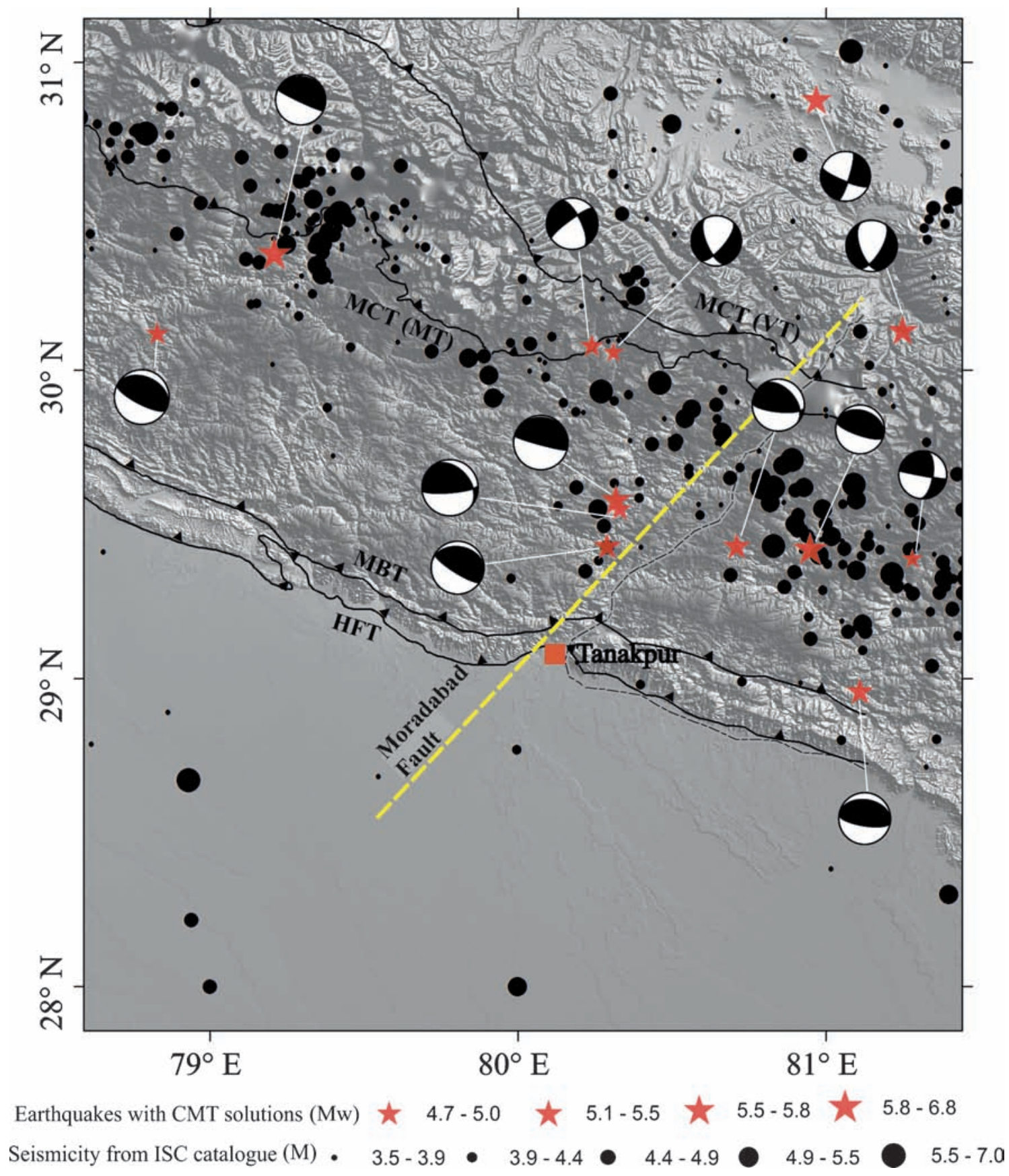

Figure 11. The seismicity map of the Kumaun and western Nepal region. The focal mechanisms are plotted for the earthquakes Mw>4.5. (Trace of Moradabad Fault: Godin and Harris 2014.)

brought up the Siwalik rocks over the Quaternary alluvia (Talukdar and Sudhakar 1972). The mountain front was affected during the tectonic upheaval along the HFT triggering massive landslides and debris flows on the slopes of the destabilised mountain (Valdiya 2003). The steepness of slope in this area can also be explained in terms of shortening rates. The balanced cross-section of the SubHimalayan rocks in the Tanakpur area, carried out by Dubey et al. (2001), suggests a shortening of $49 \%$ or $11.3 \mathrm{~km}$, while balanced cross-section estimates of the Himalaya suggest minimum shortening of $\sim 400 \mathrm{~km}$ between 55 and $40 \mathrm{Ma}$ and a total Himalayan shortening of $\sim 1100 \mathrm{~km}$ between $55 \mathrm{Ma}$ and present day (Guillot et al. 2003). The geometry of the drainage basins is elongated. Most of the small drainage basins in the source region that face south are valleys carved out by landslides (figure 5e). Apart from the steep slopes, the bedrock making up the slope is traversed by a high number of joints. The intersecting joints form wedges towards the open slopes, most of the failures are related to wedge failure. The combination of steep slopes and the intersecting joints have destabilised the slopes that give way to landslides during the rainy season. The available data of 
annual rainfall in the region for the last 108 years has been $1900 \mathrm{~mm} /$ year with a maximum rainfall during the months of July and August being $\sim 600 \mathrm{~mm}$ on average (Goswami and Yhokha 2010). In many humid uplands and the Himalaya, landscape evolution is dominated by landsliding across a wide range of length scales (Anderson 1994; Gerrard 1994; Greenbaum et al. 1995; Schmidt and Montgomery 1995; Burbank et al. 1996; Valdiya 1992).

Aggradational landforms in Tanakpur area are dominated by fans that are deposited by streams laden with landslide debris. The landslide debris fans have been incised by a number of streams, thereby exposing more than $50 \mathrm{~m}$ of the fan sediments (figures $2 \mathrm{~b}, 3 \mathrm{a}, \mathrm{c}$ ). Compositionally the fans are homogenous, in the sense that they are entirely composed of the Siwalik clasts, though reworking by the Kali River in the distal part of fans. The fans are tectonically driven, as the bedrocks are transported along the HFT and the displaced rocks have not only attained great height but have also endured brittle deformation during the successive phase of uplift along the HFT (Valdiya 2003). These conditions in conjunction with the precipitation favours slope failure of various kinds. In the Tanakpur area, the sediments making up the fans are supplied by landslides, which in turn are related to tectonic activities of the HFT and its splay thrust. Valdiya (1992) has suggested that landslides in Tanakpur area are of huge dimensions and on a very extensive scale is related to tectonic activity. A comparison on landslides that took place in Tanakpur area between 192021 and 2004 suggests three-fold increase in landslides (Goswami 2012). The deposition of alluvial fans in the Tanakpur area is a continuum process where active deposition is still taking place. The most recent deposition took placed in 2010, where a section of road between Tanakpur-Thuli Gaon was completely covered by sediments.

The tectonic activity along the HFT has been documented from various segments of the Himalayan front from Indus River, Pakistan, up to the Dibang River (a major tributary of the Brahmaputra River) in north-eastern Assam, India (Nakata 1972, 1975; Armbruster et al. 1978; Valdiya et al. 1992; Valdiya 1992; Luirei et al. 2014; Agarwal et al. 2009, 2012; Srivastava et al. 2013). Tectonic activity along the HFT has been deduced through tectonic geomorphology, paleoseismology, fluvial incision rate and convergence rates along the HFT (Nakata 1972; Wesnousky et al. 1999; Lavé and Avouac 2000; Valdiya 2003; Philip et al. 2012). At Senapani, west of Tanakpur, lateral erosion by streams has exposed thick Quaternary deposits in the HFT zone. Uplift along the HFT resulted in increasing the inclination of the tilted bedrock and tilting the overlying horizontally deposited terrace sediments. The tilted terrace has been imposed by a later phase of uplift along the HFT, as the tilted sediments have been faulted by reverse faults producing many fault-related features in the Quaternary sediments. The faulting event has also made the inclined laminations horizontal to tilt in NW direction. In the west of the present study region, at Kala Amb, Philip et al. (2012) reported two large paleoseismic events on the basis of surface displacement and liquefaction, as evident from the presence of sand dykes. The first event took place between $29.3 \mathrm{ka}$ and $17 \mathrm{ka}$ and the second event between $5.8 \mathrm{ka}$ and $2 \mathrm{ka}$. Paleoseismic records are also reported from different sites of the Frontal Himalaya (Wesnousky et al. 1999; Kumar et al. 2001; Malik et al. 2003, 2010). Paleoseismological studies have also been carried out along the HFT in the southeastern Nepal where 4-m displacement is estimated to have occurred $\sim 1.2 \mathrm{ka}$ (Upreti et al. 2000). Active tectonic studies on the uplift along the HFT has also been documented from various sites of the HFT on the basis of uplift terrace, encased strath terrace, convergent rate, offset terrace and on structural and morphological evidences (Wesnousky et al. 1999; Mugnier et al. 2004; Parkash et al. 2011). Effects of neotectonics activity on geomorphic features are also reported from the foothills of the eastern Himalaya (Luirei and Bhakuni 2008; Devi et al. 2011; Bhakuni et al. 2017). In the present study, a displacement of $\sim 1.0 \mathrm{~m}$ is observed within the laminated terrace deposit with other host of deformed structures in the terrace deposits. North-west of Tanakpur uplift along the HFT has resulted in the incising of the pre-Siwalik bedrock, as well as the overlying terrace deposit by Dhana Gad (figure 4a).

The lateral variation in structural complexities along the segmented Himalayan arc may be controlled by the presence of subsurface ridges on the underthrusting Indian plate (Valdiya 1976; Arora et al. 2012). This implies that the KasganjTanakpur spur including the neotectonic Moradabad Fault may have played the causative role in folding of the mountain front in Tanakpur area as described above.

\section{Conclusions}

The folding of the mountain front in the Tanakpur area is a result of transverse tectonics related to the neotectonic transverse Kasganj-Tanakpur Spur bounded by active faults, which propagate below the Himalayan mountain front. The area is constituted mainly by various levels of coalescing fans and terraces. Tectonically induced incision of terrace and bedrock, and truncation of fan suggest 
neotectonic activity. Fans sediments are supplied from the south-facing hill slopes that are very steep, traversed by a network of joint sets associated with the neotectonic activity of the HFT. The sudden gain in height and the sheared nature of the bedrock in the mountain front resulted from uplift along the HFT and along its splay thrust. Tilting of geographic surfaces and deformation of terraces suggest differential tectonic upheavals along the HFT. The role of transverse fault tectonics in the formation of the curvature cannot be ruled out.

\section{Acknowledgements}

The authors are grateful to the Director, Wadia Institute of Himalayan Geology, Dehradun, for providing the necessary facilities and permission to carry out the study. The authors are grateful to the two anonymous reviewers for critically reviewing the manuscripts and for their constructive suggestions. Dr V C Thakur is duly acknowledged for fruitful discussions.

\section{References}

Agarwal K K and Sharma V K 2011 Quaternary tilt-block tectonics in parts of Eastern Kumaun Himalaya, India; Z. Geomorphol. 55 197-208.

Agarwal K K, Bali R, Kumar G M, Srivastava P and Singh P V 2009 Active tectonics in and around Kimin-Ziro area, Lower Subansiri District, Arunachal Pradesh, NE India; Z. Geomorphol. 53 109-120.

Agarwal K K, Prakash C, Ali S N and Jahan N 2012 Morphometric analysis of the Ladhiya and Lohawati River basins, Kumaun Lesser Himalaya, India; Z. Geomorphol. 56 201-224.

Anderson R S 1994 Evolution of the Santa Cruz mountains, California, through tectonic growth and geomorphic decay; J. Geophys. Res. 9 20,161-20,179.

Allen P A and Hovius N 1998 Sediment supply from landslide dominated catchments; Implications for basinmargin fans; Basin Res. 10 19-35.

Armbruster J, Seeber L and Jacob K H 1978 The northwestern termination of the Himalayan mountain front: Active tectonics from microearthquakes; J. Geophys. Res. 83 269-282.

Armijo R, Tapponnier P, Mercier J L and Ton-Lin H 1986 Quaternary extension in south Tibet: Field observations and tectonic implications; J. Geophys. Res. 91 13,80313,872 .

Arora B R, Gahalaut V K and Kumar N 2012 Structural control on along-strike variation in the seismicity of the northwest Himalaya; J. Asian Earth Sci. 57 15-24.

Bhakuni S S, Luirei K, Kothyari G C and Imsong W 2017 Transverse tectonic structural elements across Himalayan mountain front: Implication of superposed landform development on analysis of neotectonics, eastern Arunachal Himalaya, India; Geomorphology, doi: 10.1016/j.geomorph.2016.12.025.

Blissenbach E 1954 Geology of alluvial fans in semi-arid regions; Geol. Soc. Am. Bull. 65 175-190.

Burbank D W, Leland J, Fielding E, Anderson R S, Brozovic N, Reid M R and Duncan C 1996 Bedrock incision, rock uplift and threshold hillslopes in the northwestern Himalayas; Nature 379 505-510.

Davis W M 1938 Sheetfloods and streamfloods; Geol. Soc. Am. Bull. 49 1337-1416.

DeCelles P G, Gray M B and Ridgway K D 1991 Kinematic history of foreland uplift from Paleocene synorogenic conglomerate: Beartooth Range, Wyoming and Montana; Geol. Soc. Am. Bull. 103 1458-1475.

Devi R K M, Bhakuni S S, Phukan M K and Duarah R 2011 Neotectonic study along mountain front of northeast Himalaya, Arunachal Pradesh, India; Environ. Earth Sci. $63751-762$.

Dubey A K, Misra R and Bhakuni S S 2001 Eratic shortening from balanced cross-sections of the western Himalayan foreland basin: Causes and implications for basin evolution; J. Asian Earth Sci. 19 765-775.

Dziewoński A, Chou T-A and Woodhouse J H 1981 Determination of earthquake source parameters from waveform data for studies of global and regional seismicity; J. Geophys. Res. 86 2825-2852.

Ekström G, Nettles M and Dziewoński A M 2012 The global CMT project 2004-2010: Centroid-moment tensors for 13,017 earthquakes; Phys. Earth Planet. Inter. 200-201 $1-9$.

Gahalaut V K and Arora B R 2012 Segmentation of seismicity along the Himalayan arc due to structural heterogeneities in the underthrusting Indian plate and overriding Himalayan wedge; Episodes $\mathbf{3 5}$ 493-500.

Gahalaut V K, Rajput S and Kundu B 2011 Low seismicity in Bhutan Himalaya and the Shillong Plateau earthquake; Phys. Earth Planet. Inter. 186 97-102.

Gansser A 1981 The geodynamic history of the Himalaya; In: Zagros-Hindu Kush-Himalaya - geodynamic evolution (eds) Gupta H K and Delany F M; Am. Geophys. Union, Washington D C, pp. 111-121.

Gerrard J 1994 The landslide hazard in the Himalayas: Geological control and human action; Geomorphology 10 221-230.

Godin L and Harris L B 2014 Tracking basement cross-strike discontinuities in the Indian crust beneath the Himalayan orogen using gravity-data relationship to upper crustal faults; Geophys. J. Int. 198 198-215.

Goswami P K 2012 Geomorphic evidences of active faulting in the northwestern Ganga Plain, India: Implications for the impact of basement structures; Geosci. J. 16 289-299.

Goswami P K and Pant C C 2007 Geomorphology and tectonics of Kota-Pawalgarh Duns, Central Kumaun Sub-Himalaya; Curr. Sci. 92 685-690.

Goswami P K and Pant C C 2008 Morphotectonic evolution of the Binau-Ramganga-Naurar transverse valley, southern Kumaun Lesser Himalaya; Curr. Sci. 94 1640-1645.

Goswami P K and Yhokha A 2010 Geomorphic evolution of the piedmont zone of the Ganga plain, India: A study based on remote sensing, GIS and field investigation; Int. J. Remote Sens. 31 5349-5364.

Goswami P K and Deopa T 2012 Quaternary block-tilting in southern Himalayan ranges of eastern Uttarakhand, India; Z. Geomorphol. 57 45-60.

Goswami C C, Mukhopadhyay D and Poddar B C 2013 Geomorphology in relation to tectonics: A case study from the eastern Himalayan foothills of West Bengal, India; Quat. Int. 298 80-92.

Greenbaum D, Tutton M, Bowker M, Browne T, Buleka J, Greally K, Kuna G, McDonald A, Marsh S, O'Connor E and Tragheim D 1995 Rapid methods of landslide hazard mapping: Papua New Guinea case study; Brit. Geol. Surv. Tech. Rep. wc/95/27. 
Guillot S, Garzanti E, Baratoux D, Marquer D, Mahéo G and De Sigoyer J 2003 Reconstructing the total shortening history of the NW Himalaya; Geochem. Geophys. Geosyst. 4, doi: 10.1029/2002GC000484.

Gupta S 1997 Himalayan drainage patterns and the origin of fluvial megafans in the Ganges foreland basin; Geology 25 11-14.

Heward A P 1978 Alluvial fan and lacustrine sediments from the Stephanian A and B (La Magdalena, CiiieraMatallana and Sabero) coalfields, northern Spain; Sedimentology 25 451-488.

Hoek E and Bray L W 1977 Rock Slope Engineering; Institute of Mining and Metallurgy, London, 290p.

Jackson J and McKenzie D 1984 Active tectonics of the Alpine-Himalayan Belt between western Turkey and Pakistan; Geophys. J. Int. 77 185-264.

Karunakaran C and Ranga Rao A 1979 Status of exploration for hydrocarbons in the Himalayan region - contribution to stratigraphy and structure; Geol. Surv. India Misc. Publ. 41 1-66.

Kotlia B S, Phartiyal B, Kosaka T and Bohra A 2008 Magnetostratigraphy and lithology of Miocene-Pliocene Siwalik deposits between Tanakpur and Sukhidang, southeastern Uttarakhand Himalaya, India; Him. Geol. 29 127-136.

Kumar S, Wesnousky S G, Rockwell T K, Ragona D, Thakur V C and Seitz G G 2001 Earthquake recurrence and rupture dynamics of Himalayan Frontal Thrust India; Science 294 2328-2331.

Kumar R, Ghosh S K, Sangode S J and Thakur V C 2002 Manifestation of Intra-Foreland thrusting in the Neogene Himalaya foreland basin fill; J. Geol. Soc. India $\mathbf{5 9}$ $547-560$.

Kumar M S 2004 Magnetic polarity stratigraphy of the Siwalik sediments from Ramganga Basin, NW Himalaya; J. Geol. Soc. India 64 199-210.

Lavé J and Avouac J 2000 Active folding of fluvial terraces across the Siwalik Hills, Himalayas of central Nepal; J. Geophys. Res. 105 5735-5770.

Luirei K and Bhakuni S S 2008 Geomorphic imprints of neotectonic activity along the frontal part of eastern Himalaya, Pasighat, East Siang District, Arunachal Pradesh; J. Geol. Soc. India 71 502-512.

Luirei K, Bhakuni S S, Srivastava P and Suresh N 2014 Late Pleistocene-Holocene tectonic activities in the frontal part of NE Himalaya between Siang and Dibang river valleys, Arunachal Pradesh, India; Z. Geomorphol. 56 477-493.

Malik J N and Nakata T 2003 Active faults and related late Quaternary deformation along the northwestern Himalayan frontal zone, India; Ann. Geophys. 46 917-936.

Malik J N, Nakata T, Philip G and Virdi N S 2003 Preliminary observations from trench near Chandigarh, NW Himalaya and their bearing on active faulting; Curr. Sci. 85 1793-1799.

Malik J N, Sahoo A K, Shah A A, Shinde D P, Juyal N and Singhvi A K 2010 Paleoseismic evidence from trench investigation along Hajipur Fault, Himalayan Frontal Thrust, NW Himalaya: Implications of the faulting pattern on landscape evolution and seismic hazard; J. Struct. Geol. 32 350-361.

Mugnier J L, Huyghe P, Leturmy P and Jouanne F 2004 Episodicity rates of thrust sheet motion in the Himalayas (western Nepal); In: Thrust tectonics and hydrocarbon systems (ed.) McClay K, Am. Assoc. Petrol. Geol. Memoir 82 91-114.

Nakata T 1972 Geomorphic history and crustal movements of the foot-hills of the Himalaya; Tohoku University Science Reports, 7th Series, Japan 22 39-177.

Nakata T 1975 On Quaternary tectonics around Himalayas; Tohoku University Science Reports, 7th Series, Japan 22 111-118.
Nakata T 1989 Active faults of the Himalaya of India and Nepal; J. Geol. Soc. Am. Spec. Paper 232 243-264.

$\mathrm{Ni} J$ and Barazangi M 1984 Seismotectonics of the Himalayan collision zone: Geometry of the underthrusting Indian plate beneath the Himalaya; J. Geophys. Res. 89 1147-1163.

Pandey M R 1995 lnterseismic strain accumulation on the Himalayan crustal ramp (Nepal); Geophys. Res. Lett. 22 $751-754$.

Parkash B, Rathor R S, Pati P, Jakhmola R P and Singh S 2011 Convergence rates along the Himalayan Frontal Thrust inferred from terraces at Chandidevi Temple hill, Haridwar, northwestern Himalaya; Curr. Sci. 100 1426-1432.

Pathak B D 1982 Groundwater resources of Uttar Pradesh, India. In: Engineering Geoscience (ed.) Singhal B B S, pp. 111-131.

Philip G, Bhaknui S S and Suresh N 2012 Late Pleistocene and Holocene large magnitude earthquakes along Himalayan Frontal Thrust in the central seismic gap in NW Himalaya, Kala Amb, India; Tectonophys. 580 $162-177$.

Powers P M, Lillie R J and Yeats R S 1998 Structure and shortening of the Kangra and Dehra Dun re-entrants, Sub-Himalaya, India; Geol Soc. Am. Bull. 110 1010-1027.

Prakash C, Agarwal K K and Sharma V K 2015 Structural control of landslides in Eastern Kumaun Himalaya - Case study from Sukhidhang-Ladhiya section; J. Geol. Soc. India 86 507-512.

Raiverman V 2002 Foreland sedimentation; In: Himalayan tectonic regime. A relook at the orogenic process (ed.) Bisen Singh Mahendra Pal Singh, Dehradun, 371p.

Ranga Rao A and Venkataraman S 1959 Geology of the area in between Kathgodam to Tanakpur, UP India; Unpubl. ONGC Report, 31p.

Robinson D P, Das S and Watts A B 2006 Earthquake rupture stalled by a subducting fracture zone; Science $\mathbf{3 1 2}$ 1203-1205.

Sastri V V, Bhandari L L, Raju A T R and Datta A K 1971 Tectonic framework and subsurface stratigraphy of the Ganga Basin; J. Geol. Soc. India 12 222-233.

Schmidt K M and Montgomery D R 1995 Limits to relief; Science 270 617-620.

Singh I B 1996 Geological evolution of Ganga Plain - an overview; J. Paleontol. Soc. India 41 99-137.

Shukla U K and Bora D S 2003 Geomorphology and sedimentology of piedmont zone, Ganga plain, India; Curr. Sci. 84 1034-1040.

Srivastava G S, Kulshrestha A K and Agarwal K K 2013 Morphometric evidences of neotectonic block movement in Yamuna Tear Zone of Outer Himalaya, India; $Z$. Geomorphol. 57 471-484.

Steel R J 1976 Devonian basins of western Norway - Sedimentary response to tectonism and to varying tectonic context; Tectonophys. 36 207-224.

Talukdar S N and Sudhakar R 1972 Structure of the southern edge of the Himalaya in north India: Calcutta; Geol. Surv. India Misc. Publ. 15 185-194.

Thakur V C 2004 Active tectonics of Himalayan Frontal Thrust and seismic hazard to Ganga plain; Curr. Sci. 86 $1554-1560$.

Tiwari G, Samanta U, Kumar A, Upadhyay P, Gupta A, Arora H K, Shah V R and Baruah A K 1991 Geochemical evaluation of source organics of sediments of Himalayan foothills: KDMIPE ONGC Dehradun, Internal report.

Upreti B N, Nakata T, Kumahara Y, Yagi H, Okumura K, Rockwell T K, Virdi N S and Maemoku H 2000 The latest active faulting in southeast Nepal; In: Active Fault Research for the New Millennium: Proceedings of 
the Hokudan International Symposium and School on Active Faulting (eds) Okumura K, Takada K and Goto H, Hokudan Co. Ltd., pp. 533-536.

Valdiya K S 1976 Himalayan transverse faults and folds and their parallelism with subsurface structures of the northern Indian Plains; Tectonophys. 32 353-386.

Valdiya K S 1986 Neotectonic activities in the Himalayan belt; In: Proceedings, International Symposium on Neotectonics in South Asia, Geological Survey of India, Dehradun, pp. 241-267.

Valdiya K S 1992 The main boundary thrust zone of Himalaya, India; In: Major Active Faults of the World: Results of IGCP Project 206 (eds) Bucknam R C and Hancock P L, Annals Tectonicae 6 54-84.
Valdiya K S 2003 Reactivation of Himalayan Frontal Fault: Implications; Curr. Sci. 85 1031-1040.

Valdiya K S, Sharma P K, Rana R S and Dey P 1992 Active Himalayan Frontal Fault, Main Boundary Thrust and Ramgarh Thrust in southern Kumaun; J. Geol. Soc. India 40 509-528.

Wesnousky S G, Senthil K, Mohindra R and Thakur V C 1999 Uplift and convergence along the Himalayan Frontal Thrust; Tectonics 18 967-976.

Yeats R S, Nakata T, Farah A, Fort M, Mirza M A, Pandey M R and Stein R S 1992 The Himalayan frontal fault system; In: Major Active Faults of the World: Results of IGCP Project 206 (eds) Bucknam R C and Hancock P L, Annales Tectonicae 6 85-98.

MS received 14 July 2016; revised 31 August 2016; accepted 5 October 2016

Corresponding editor: RAJesh Kumar SRIVAStava 